\title{
Identification of the Significance and Relevant Barriers of Sustainability Aspects at the Workers' Level in the Garments Industry of Bangladesh
}

\author{
Md. Zulfikar Hasan \\ Department of Textile Engineering, \\ Ahsanullah University of Science \\ \& Technology, Dhaka, Bangladesh
}

\author{
Joyjit Ghosh* \\ Department of Textile Engineering, \\ Ahsanullah University of Science \\ \& Technology, Dhaka, Bangladesh \\ joyjit.te@aust.edu
}

\author{
Amit Chakrabortty \\ Department of Textile Engineering, \\ Ahsanullah University of Science \\ \& Technology, Dhaka, Bangladesh
}

\begin{abstract}
Nowadays Sustainability is one of the major concerning issues in the Garments Industry of Bangladesh. As the garment industry of Bangladesh is rising, both buyers and manufacturers are now more aware than ever before about the welfare and worker friendly environment in the garments. The purpose of the study is to find out the significance level along with the respective barriers of sustainability at the blue collar workers' level in Bangladeshi Garments industry. In this purpose, a semistructured questionnaire was used to interview the respondents as well as to collect the data. The statistical analysis of the collected data was done by SPSS software and the data were also used to find out the barriers related to each aspect. The analysis depicted economic aspect as the most significant predictor, whereas environmental-economic aspect was portrayed as the least significant one. The findings of this project will be very helpful for the garment industry owners to realize the significance of different sustainability aspects as well as to convert the related barriers into success factors.
\end{abstract}

\section{Keywords}

Sustainability; Significance level; Relevant barriers; Blue collar workers; Statistical analysis

\section{INTRODUCTION}

Sustainability is related to three major interconnected domains or pillars such as environment, economic and social whereas cultural, technological and political are considered the subdomains of sustainable development. Without compromising the ability of future generations, sustainable development similarly fulfills the needs of the present. Brundtland Report for the World Commission on Environment and Development (1987) introduced the term of sustainable development [1]. For the survival of humans and other organisms, healthy ecosystems and environments are essential. Human economies and natural ecosystems are introduced in the field of Ecological economics [2].
Sustainability is a social challenge that involves international and national law, urban planning and transport, local and individual lifestyles and ethical consumerism [3]. It also deals with green technologies, renewable energy and sustainable fission and fusion power in a flexible and reversible manner [4]. Sustainable development is a universal approach and progressive processes that lead us to the end point of sustainability [5]. In 2012, Gimenez and Tachizawa carried out a survey on sustainability in supply chain where both assessment and collaboration had a positive impact on environmental performance and corporate social responsibility. Some enablers of these practices are identified [6]. In 2015, Sarfaraz Hashemkhani Zolfani, Maedeh Sedaghat, Reza Maknoon and Edmundas Kazimieras Zavadskas figured out that the goal of comprehensive tourism planning is to achieve economic growth and efficiency, ensuring efficiency and social equity by solving the basic needs of the population and on the basis of stable and continuous environmental systems [7].In 2017, the findings of Elfriede Penz, Eva Hofmann and Barbara Hartl included that sustainable behavior positively correlated with their preference for certified tour operators, awareness of sustainable tourism products and prospective tourists' values and attitudes on sustainable behavior positively correlated with their preference for certified tour operators [8].There are three critical success factors have been common across all organizations and the success of their sustainability programs which are commitment to improvement, commitment to engagement and commitment to leverage [9]. The aims of commercial sustainability teams and financial teams are not in the same line. Climate change and water scarcity are not being entirely combined into long-term business strategy. [10].Sustainability in RMG business operation is an evolving issue for Bangladeshi entrepreneurs after Tazreen and Rana Plaza incidents. RMG industry of Bangladesh is the main catalyst for the country's economy which is accused by the buyer for lack of execution of sustainability issues in the factories. Environmental sustainability is the evolving issue at the present stage of industrialization. Nowadays apparel buyers are aiming on the eco-friendly way of production. Bangladesh RMG industry tries to adopt cleaner and improved technology and management for better environment to achieve its objectives [11]. The purpose of the study is to identify the issues related to each sustainability aspect; secondly, to find out the significance 
level of the sustainability aspects and finally, to explore the barriers related to each sustainability aspect.

\section{METHODS}

2.1 SPSS

Statistical Package for the Social Sciences (SPSS) was first introduced in 1968. SPSS was developed by IBM in 2009 which is officially known as IBM SPSS Statistics. The IBM SPSS ${ }^{\circledR}$ software platform deals with advanced statistical analysis. It also helps the organization to find new opportunities, improve efficiency and minimize risk [10].

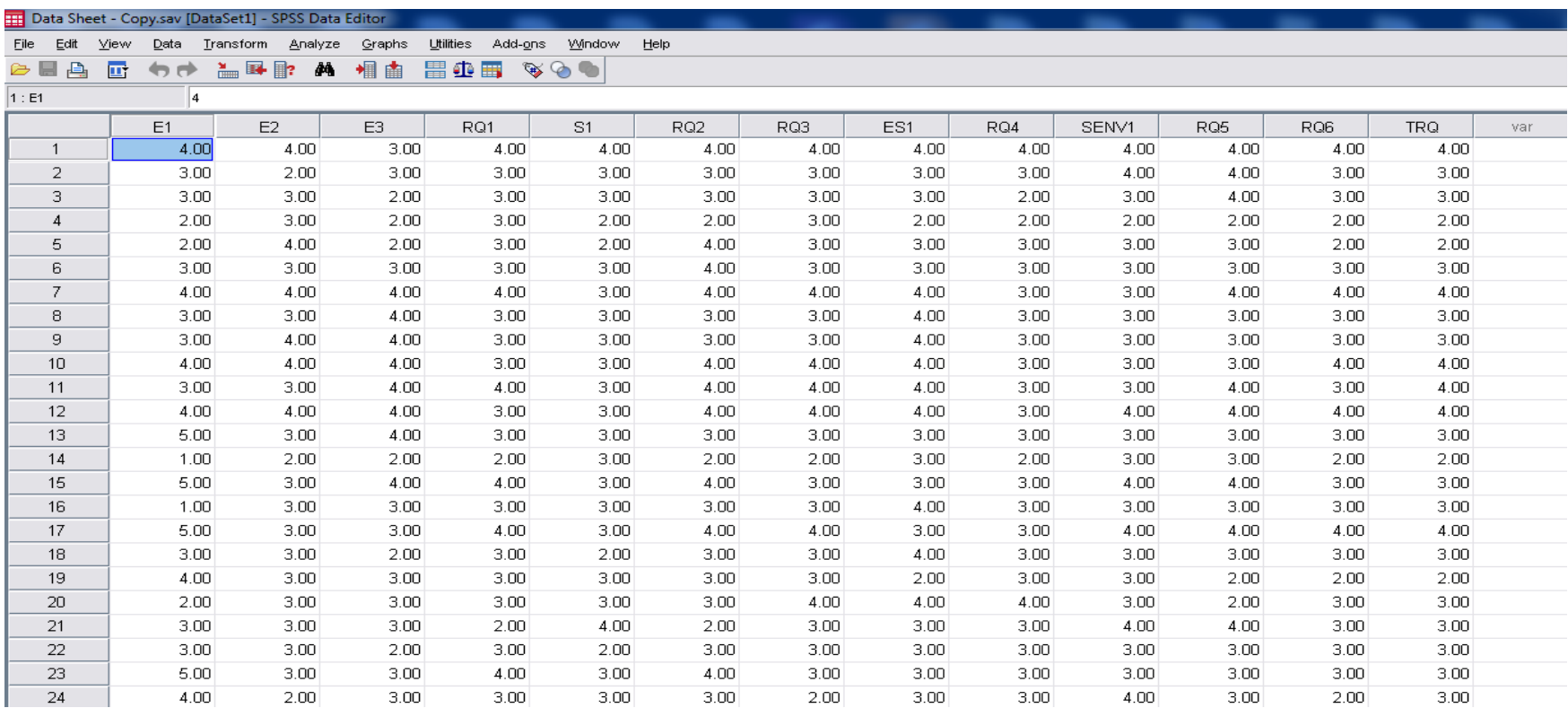

Figure 1: Data view in SPSS

In the data view of Figure 1, the questionnaire's questions number and their corresponding answers of the target population was shown. The answers were converted into such way that they can be put in the software and analyze. In the variable view of Figure 2, this software showed the question types and their characteristics.

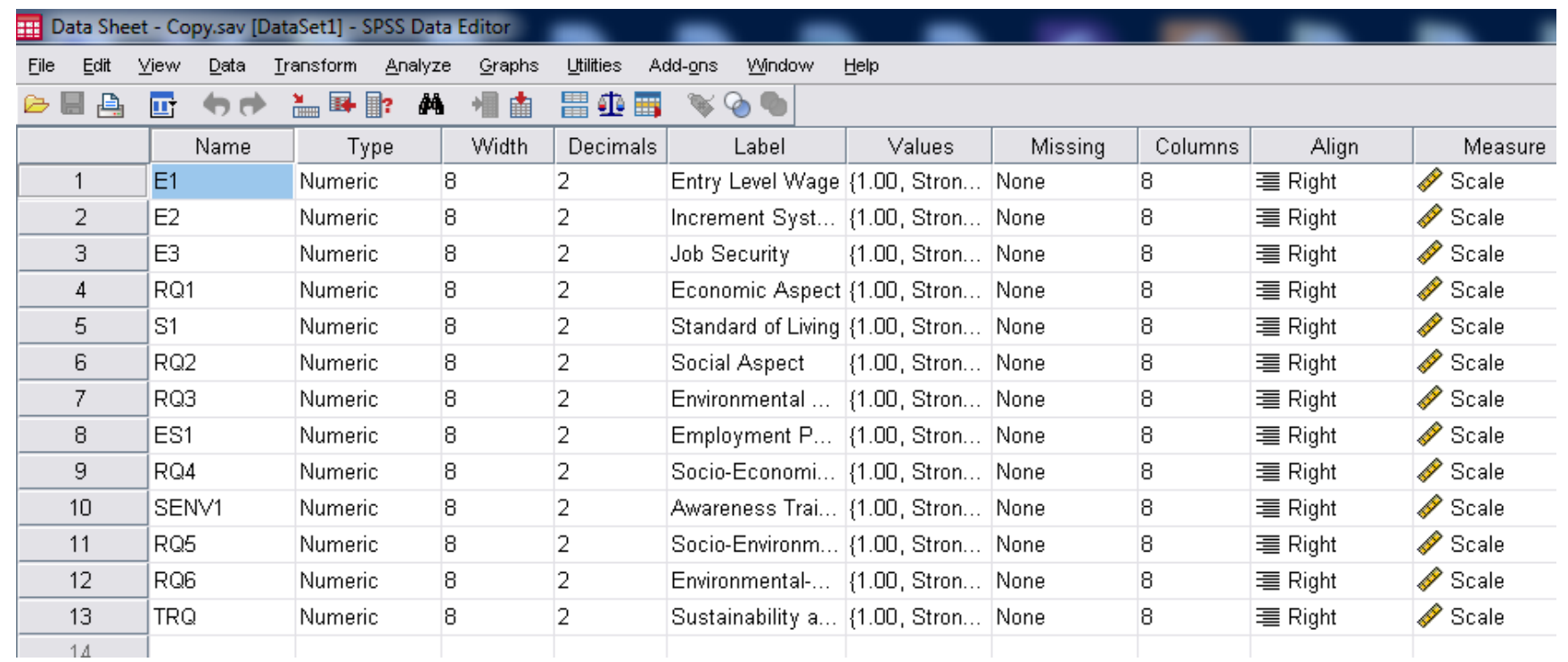

Figure 2: Variable view in SPSS 


\subsection{Cronbach's Alpha}

Cronbach's alpha is a suitable for estimating the reliability or internal consistency of a composite score. Now, what on Earth does that mean? Let's start with reliability. Say an individual takes a Happiness Survey. Your happiness score would be highly reliable (consistent) if it produces the same or similar results when the same individual re-takes your survey, under the same conditions. Theoretically, Cronbach's alpha results should give you a number from 0 to 1 , but you can get negative numbers as well. A negative number indicates that something is wrong with your data-perhaps you forgot to reverse score some items. The thumb rule of Cronbach's alpha is that .70 and above is good, .80 and above is better, and .90 and above is best. But it has some limitations: scores that have a low number of items associated with them tend to have lower reliability, and sample size can also influence your results for better or worse. However, it is still a widely used measure, so if your committee is asking for proof that your instrument was internally consistent or reliable, Cronbach's alpha is a good way to go [12].

\subsection{Regression}

Regression is a predictive analysis which deals with two things such as does a set of predictor variables and outcome variables.

Regression is used to explain the relationship between one dependent variable and one or more independent variables. The simplest form of the regression equation with one dependent and one independent variable is defined by the formula $y=c+b x$, where $\mathrm{y}=$ estimated dependent variable score, $\mathrm{c}=$ constant, $\mathrm{b}=$ regression coefficient, and $\mathrm{x}=$ score on the independent variable [12].

\subsubsection{Multiple Regression}

Multiple regressions generally explains the relationship between multiple independent or predictor variables and one dependent or criterion variable. A dependent variable is demonstrated as a function of several independent variables and corresponding coefficients of constant term. Multiple regressions require two or more predictor variables, and this is why it is called multiple regressions [12].

\subsection{Coefficient of Determination ( $R$ square)}

It was used to determine how much variance two variables, share, or how much variance is explained, or accounted for, by a set of variables (predictors) in an outcome variable. The values can range from 0.00 to 1.00 , or 0 to $100 \%$. The coefficient of determination is a measure of accuracy of the regression model. In simple linear regression analysis, the correlation coefficient (r) is the square of $r$ value between the two values. In a multiple linear regression analysis, $R^{2}$ is known as the multiple correlation coefficient of determination. It helps to describe how well a regression line fits (a.k.a., goodness of fit). An $R^{2}$ value of 0 indicates that the regression line does not fit the set of data points and a value of 1 indicates that the regression line perfectly fits the set of data points. By definition, $R^{2}$ is calculated by one minus the Sum of Squares of Residuals $\left(S S_{\text {error }}\right)$ divided by the Total Sum of Squares $\left(S S_{\text {total }}\right): R^{2}=1-$ $\left(S S_{\text {error }} / S S_{\text {total }}\right)$. In the case of a multiple linear regression, the predictor variables are too correlated with one another (referred to as multicollinearity) that can cause the coefficient of determination to be higher in value. The Adjusted $R$ Squared (Adjusted Coefficient of Determination) should be interpreted for a multicollinearity regression model. The Adjusted $R^{2}$ can take on negative values, but should always be less than or equal to the Coefficient of Determination. Note: The Adjusted $R^{2}$ will only increases if more predictors' variables are added to the regression model. Inversely, the Coefficient of NonDetermination explains the amount of unexplained, or unaccounted variance between two variables, or a set of variables (predictors) in an outcome variable where the Coefficient of Non-Determination is simply $1-R^{2}[12]$.

\subsection{ANOVA}

An analysis of variance (ANOVA) is an appropriate statistical analysis which is used for assessing the differences between groups on a continuous measurement (Tabachnick \& Fidell, 2013). Depending on the goal of the research, there are several types of ANOVAs that can be utilized. Between-Subjects ANOVA: One of the most common forms of an ANOVA is a between-subjects ANOVA. This analysis is applied for examining the differences between independent groups on a continuous level variable. There are two types of ANOVA such as one-way ANOVAs and factorial ANOVAs. A one-way ANOVA is used for assessing the differences in one continuous variable between one grouping variable whereas a factorial ANOVA is suitable for two or more independent variables [12].

\subsubsection{Within-Subjects ANOVA}

A within-subjects ANOVA is known as a repeated measure ANOVA which is appropriate for examining the differences in a continuous level variable over time. ANOVA is frequently used for pretest and posttest design which is not limited to only two time periods. [12].

\subsubsection{ANCOVA}

An analysis of covariance (ANCOVA) is suitable for examining the differences in a continuous dependent variable between groups. The "C" in ANCOVA means that a covariate is being entered into the model which can be applied to a betweensubjects design, a within-subjects design, or a mixed-model design. ANCOVAs are frequently used in experimental studies when the researcher wants to account for the effects of an antecedent (control) variable [12].

\subsubsection{MANOVA}

A multivariate analysis of variance (MANOVA) is an extension on the ANOVA which is appropriate for examining the differences in multiple continuous level variables between groups. The MANOVA can be conducted with multiple independent variables, and can also include covariates [12].

\subsection{Bivariate Correlation}

The Bivariate (Pearson) Correlation generates a sample correlation coefficient, $r$, which indicates the strength and direction of linear relationships between pairs of continuous variables [12]. 


\section{Identification of the Significance and Relevant Barriers of Sustainability Aspects at the Workers' Level in the Garments Industry of Bangladesh}

\subsection{Beta}

The value of Beta represents the slope of the line between the predictor variable and the dependent variable in regression table [12].

\subsection{Multicollinearity}

Multicollinearity indicates a very high intercorrelations or interassociations among the independent variables. It is a disturbance in the data, and present in the data the statistical inferences made about the data may not be reliable. There are certain reasons why multicollinearity occurs such as it is caused by an inaccurate use of dummy variables. It is due to the inclusion of a variable which is computed from other variables in the data set. Generally, occurs when the variables are highly correlated to each other [12].

\subsection{Tolerance}

The tolerance measures the influence of one independent variable on all other independent variables; the tolerance is calculated with an initial linear regression analysis. Tolerance is derived by $\mathrm{T}=1-\mathrm{R}^{2}$ for these first step regression analysis. With $\mathrm{T}<0.1$ there might be multicollinearity in the data and with $\mathrm{T}<0.01$ there certainly is [12].

\subsection{VIF}

VIF stands for Variance Inflation Factor. VIF assesses the factors which are correlated to each other and could affect $p$ values as well as indicates the model isn't be as reliable. If a VIF is greater than 10 , then the multicollinearity is high and the variation will seem larger and the factor will appear to be more influential than it is. If VIF is closer to 1 , then the model is much stronger, as the factors are not impacted by correlation with other factors [14].

\subsection{Pearson Correlation}

In statistic, correlation is a bivariate analysis that measures the strength of association between two variables and the direction of the relationship. The strength of correlation coefficient varies between +1 and -1 where \pm 1 indicates a perfect degree of association between the two variables. The relationship between the two variables will be weaker when the correlation coefficient value becomes 0 . The a + sign indicates a positive relationship whereas a - sign indicates a negative relationship. Pearson $r$ correlation is used to measure the degree of the relationship between linearly related variables.

The following formula is used to calculate the Pearson $r$ correlation:

$r=\frac{N \sum x y-\sum(x)(y)}{\sqrt{\left[N \sum\left(x^{2}-\sum\left(x^{2}\right)\right]\left[N \sum\left(y^{2}-\sum\left(y^{2}\right)\right]\right.\right.}}$

Where, $r=$ Pearson $\mathrm{r}$ correlation coefficient; $\mathrm{N}=$ number of observations; $\sum x y=$ sum of the products of paired scores, $\sum x=$ sum of $\mathrm{x}$ scores; $\sum \mathrm{y}=$ sum of $\mathrm{y}$ scores; $\sum \mathrm{x} 2=$ sum of squared $\mathrm{x}$ scores; $\sum \mathrm{y} 2=$ sum of squared y scores [12].

\section{METHODOLOGY}

At first, a literature review was done to conduct the study. In this study, the significance as well as the barriers related to each sustainability aspects were assessed by conducting a survey by using a questionnaire (semi structured: open-ended and close ended) based on sustainability related topics. The data were collected from the target group who were the blue collar workers' of Bangladeshi garments industries. The factories from which we collected the data were Creative Collection Ltd., AOne Polar Ltd, NAZ Bangladesh Ltd., Opex \& Sinha Group, A4 Apparels, Talisman Ltd. The target population of the survey was 100. The data were collected on the basis of Likert 5.00 scale for clear, deeper and appropriate response. Finally, quantitative analysis was done on the basis of close-ended questions by using SPSS software and alternative analysis was done on the basis of open-ended questions to explore the significance level and barriers of the sustainability aspects respectively at the blue collar workers' level.

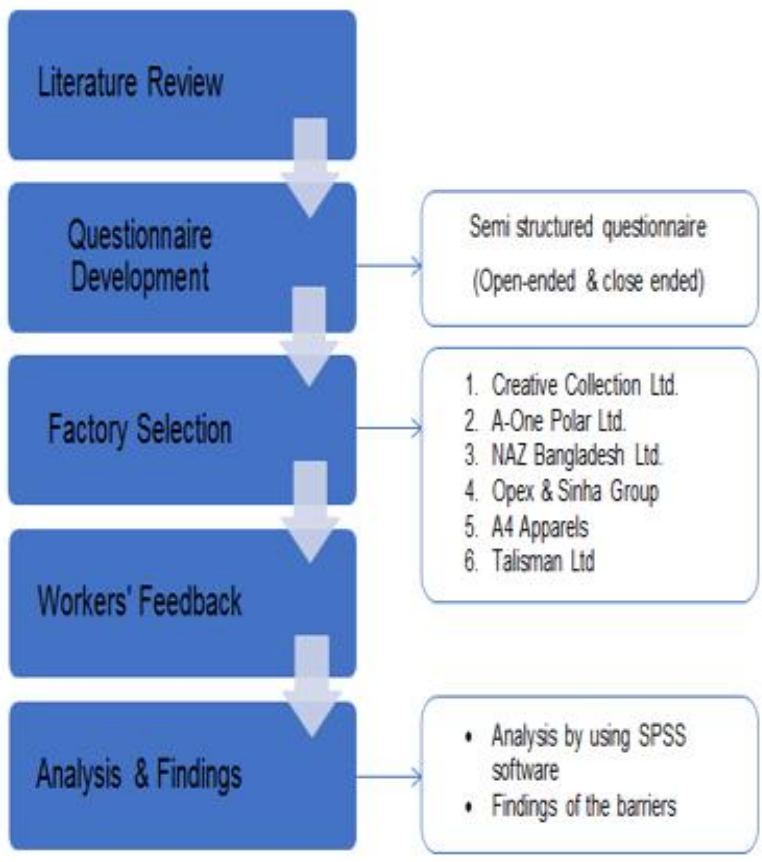

Figure 3: Methodology

\section{RESULTS AND DISCUSSIONS}

\subsection{Statistical Analysis}

\subsubsection{Reliability Test}

To check the reliability of collected data Cronbach's Alpha was conducted. Cronbach's Alpha indicates overall reliability for a set of variables. The standard value of Cronbach's Alpha is 0.70 . In this study the value of Cronbach's Alpha is 0.835 illustrates high level of internal consistency for the scale of this sample.

Table 1: Reliability Test

\begin{tabular}{|c|c|c|}
\hline Cronbach's Apha & Cronbach's Apha Based on Standadcized llems & Nof llems \\
\hline 0.835 & 0.830 & 7 \\
\hline
\end{tabular}




\subsubsection{Multiple Regression Analysis}

Table 2: Regression (Model Summaary)

\begin{tabular}{|c|c|c|c|c|}
\hline Model & $R$ & R Square & Adjusted R Square & Std. Error of the Estimate \\
\hline 1 & $0.957^{\mathrm{a}}$ & 0.915 & 0.911 & 0.231 \\
\hline
\end{tabular}

a. Predictors: (Constant), Environmental-Economic Aspect, Socio-Economical Aspect, Socio-Environmental Aspect, Social Aspect, Environmental Aspect, Economic Aspect. A regression analysis is called Multiple Regression Analysis if there is one Dependent Variable (DV) and two or more Independent Variables (IV) or Predictors. As there is one DV which is sustainability at Blue Collar Workers' level and six predictors which are Environmental-Economic Aspect, Socio-Economical Aspect, Socio-Environmental Aspect, Social Aspect, Environmental Aspect, Economic Aspect so this regression is a Multiple Regression. The value of R2 in the model summary Table 2 is 0.915 which means the predictors account for $91.5 \%$ of the variance in the Sustainability at Blue Collar Workers' Level.

\subsubsection{ANOVA}

Table 3: ANOVA

\begin{tabular}{|l|c|c|c|c|c|}
\hline Model & Sum of Squares & df & Mean Square & F & Sig. \\
\hline Regression & 65.846 & 6 & 10.974 & 204.000 & $0.000^{\mathrm{a}}$ \\
Residual & 6.079 & 113 & 0.054 & & \\
Total & 71.925 & 119 & & & \\
\hline
\end{tabular}

a. Predictors: (Constant), Environmental-Economic Aspect, Socio-Economical Aspect, Socio-Environmental Aspect, Social Aspect, Environmental Aspect, Economic Aspect b. Dependent Variable: Sustainability at Blue Collar Workers' Level.

From the ANOVA Table 3, it can be said that $\mathrm{F}(6,113)=119$, p $<0.001, \mathrm{R} 2=0.915$ which means overall of our regression analysis was statistically significant. When those six predictors were taken as group they predict sustainability at blue collar workers' Level significantly.

\subsubsection{Coefficients}

In the co-efficient Table 4, the constant is not important and it is needed to focus on the Significance columns which are $p$ values for each of the predictors. So, evaluation of each of these predictors on basis of $\alpha(0.05)$ is done. Now, it can be seen that the $\mathrm{p}$ value of the first predictor or independent variable Economic Aspect is 0.000 which means $\mathrm{p}<\alpha$. As a result, it can be said that Economic Aspect is a significant predictor of Sustainability at Blue Collar Workers' Level. The $p$ value of the Social Aspect is also a significant predictor of the Dependent Variable since the $\mathrm{p}$ value of Social Aspect is less than 0.05. However, the $\mathrm{p}$ value of the third predictor is also a significant predictor but not as significant as the first two predictors as its $\mathrm{p}$ value is higher than the first two predictors. So, from the Coefficient Table 4, it can be said that Economic Aspect explains a significant amount of variance in Sustainability at Blue Collar Workers' Level most uniquely than other predictors. Here, the sequence of the significance of the independent variables on the dependent variable can be expressed as follows: Economic Aspect $(p=0.000)>$ Social Aspect $(p=0.04)>$ Socio-Economical Aspect $(\mathrm{p}=0.013)>$ Socio-Environmental Aspect $(\mathrm{p}=0.019)>$ Environmental Aspect $(\mathrm{p}=0.024)>$ Environmental-Economic Aspect $(\mathrm{p}=0.032)$. If the value of tolerance is less than 0.1 and simultaneously the value of Variance Inflation Factor (VIF) is 10 or above then multicollinearity is present in the analysis which means very high inter-correlation among independent variables. It is therefore a type of disturbance in the data and if present in the data then the statistical inferences made about the data may not be reliable. From the coefficient Table 4, it can be clearly said that our analysis is free from multicollinearity.

Table 4: Coefficients

\begin{tabular}{|c|c|c|c|c|c|c|c|}
\hline \multirow[b]{2}{*}{ Model } & \multicolumn{2}{|c|}{$\begin{array}{c}\text { Unstandardized } \\
\text { Coefficients }\end{array}$} & \multirow{2}{*}{$\begin{array}{c}\text { Standardized } \\
\text { Coefficients } \\
\text { Beta }\end{array}$} & \multirow[b]{2}{*}{$t$} & \multirow[b]{2}{*}{ Sig. } & \multicolumn{2}{|c|}{ Collinearity Statistics } \\
\hline & $\mathbf{B}$ & $\begin{array}{l}\text { Std. } \\
\text { Error }\end{array}$ & & & & Tolerance & VIF \\
\hline (Constant) & -.572 & -133 & & -4.285 & .000 & & \\
\hline Economic Aspect & .284 & .060 & .276 & 4.696 & . & .317 & 4.155 \\
\hline Social Aspect & .220 & .052 & .206 & 4.234 & .004 & .307 & 4.608 \\
\hline $\begin{array}{l}\text { Environmental } \\
\text { Aspect }\end{array}$ & .097 & .038 & .173 & 2.613 & .024 & -178 & 2.045 \\
\hline $\begin{array}{l}\text { Socio-Economical } \\
\text { Aspect }\end{array}$ & .205 & .048 & .210 & 3.167 & .013 & .212 & 3.634 \\
\hline $\begin{array}{l}\text { Socio- } \\
\text { Environmental } \\
\text { Aspect }\end{array}$ & -195 & .043 & -182 & 2.677 & .019 & -180 & 2.991 \\
\hline $\begin{array}{l}\text { Environmental- } \\
\text { Economic Aspect }\end{array}$ & .087 & .036 & .076 & 0.571 & .032 & .354 & 4.828 \\
\hline
\end{tabular}




\section{Identification of the Significance and Relevant Barriers of Sustainability Aspects at the Workers' Level in the Garments Industry of Bangladesh}

a. Dependent Variable: Sustainability at Blue Collar Workers' Level.

\subsubsection{Regression Equation}

Sustainability at Blue Collar Workers' Level $=-0.572+$ $(0.284 \times$ Economic Aspect $)+(0.220 \times$ Social Aspect $)+$ $(0.205 \times$ Socio-Economical Aspect $)+(0.195 \times$ SocioEnvironmental Aspect $)+(0.097 \times$ Environmental Aspect $)+$ (0.087×Environmental-Economic Aspect).
From the above equation it is clear that, " 1 " point increase in Economic Aspect corresponds to " 0.284 " unit increase in Sustainability at Blue Collar Workers' Level.

\subsubsection{Pearson Correlation}

Table 5: Pearson Correlation

\begin{tabular}{|c|c|c|c|c|c|c|c|c|}
\hline & & $\begin{array}{l}\text { Sustainability at } \\
\text { Blue Collar } \\
\text { Workers' Level }\end{array}$ & $\begin{array}{c}\text { Economic } \\
\text { Aspect }\end{array}$ & $\begin{array}{l}\text { Social } \\
\text { Aspect }\end{array}$ & $\begin{array}{c}\text { Environmental } \\
\text { Aspect }\end{array}$ & $\begin{array}{c}\text { Socio- } \\
\text { Economical } \\
\text { Aspect }\end{array}$ & $\begin{array}{c}\text { Socio- } \\
\text { Environmental } \\
\text { Aspect }\end{array}$ & $\begin{array}{l}\text { Environmental- } \\
\text { Economic Aspect }\end{array}$ \\
\hline \multirow{3}{*}{$\begin{array}{l}\text { Sustainability } \\
\text { at Blue Collar } \\
\text { Workers' Level }\end{array}$} & $\begin{array}{l}\text { Pearson } \\
\text { Correlation }\end{array}$ & 1 & $.893^{* *}$ & $.828^{* *}$ & $.831^{* *}$ & $.593^{* *}$ & $.753^{* *}$ & $.824^{* *}$ \\
\hline & $\begin{array}{l}\text { Sig. } \\
\text { (2-tailed) }\end{array}$ & & .000 & .000 & .000 & .000 & .000 & .000 \\
\hline & $\mathrm{N}$ & 100 & 100 & 100 & 100 & 100 & 100 & 100 \\
\hline \multirow[t]{3}{*}{$\begin{array}{l}\text { Economic } \\
\text { Aspect }\end{array}$} & $\begin{array}{l}\text { Pearson } \\
\text { Correlation }\end{array}$ & $.893^{* *}$ & 1 & $.815^{* *}$ & $.761^{* *}$ & $.521^{* *}$ & $.689^{* *}$ & $.730^{* * *}$ \\
\hline & $\begin{array}{l}\text { Sig. } \\
\text { (2-tailed) }\end{array}$ & .000 & & .000 & .000 & .000 & .000 & .000 \\
\hline & $\mathrm{N}$ & 100 & 100 & 100 & 100 & 100 & 100 & 100 \\
\hline \multirow[t]{3}{*}{ Social Aspect } & $\begin{array}{l}\text { Pearson } \\
\text { Correlation }\end{array}$ & $.828^{* * *}$ & $.815^{* *}$ & 1 & $.706^{* * *}$ & $.466^{* *}$ & $.572^{* *}$ & $.647^{* * *}$ \\
\hline & $\begin{array}{l}\text { Sig. } \\
\text { (2-tailed) }\end{array}$ & .000 & .000 & & .000 & .000 & .000 & .000 \\
\hline & $\mathrm{N}$ & 100 & 100 & 100 & 100 & 100 & 100 & 100 \\
\hline \multirow[t]{3}{*}{$\begin{array}{l}\text { Environmental } \\
\text { Aspect }\end{array}$} & $\begin{array}{l}\text { Pearson } \\
\text { Correlation }\end{array}$ & $.831^{* *}$ & $.761^{* *}$ & $.706^{* *}$ & 1 & $.523^{* *}$ & $.625^{* *}$ & $.713^{* *}$ \\
\hline & $\begin{array}{l}\text { Sig. } \\
\text { (2-tailed) }\end{array}$ & .000 & .000 & .000 & & .000 & .000 & .000 \\
\hline & $\mathrm{N}$ & 100 & 100 & 100 & 100 & 100 & 100 & 100 \\
\hline $\begin{array}{l}\text { Socio- } \\
\text { Economical }\end{array}$ & $\begin{array}{l}\text { Pearson } \\
\text { Correlation }\end{array}$ & $.593^{* *}$ & $.521^{* *}$ & $.466^{* *}$ & $.523^{* *}$ & 1 & $.342^{* *}$ & $.592^{* *}$ \\
\hline
\end{tabular}




\begin{tabular}{|c|c|c|c|c|c|c|c|c|}
\hline Aspect & $\begin{array}{l}\text { Sig. } \\
\text { (2-tailed) }\end{array}$ & .000 & .000 & .000 & .000 & & .000 & .000 \\
\hline & $\mathrm{N}$ & 100 & 100 & 100 & 100 & 100 & 100 & 100 \\
\hline \multirow{3}{*}{$\begin{array}{l}\text { Socio- } \\
\text { Environmental } \\
\text { Aspect }\end{array}$} & $\begin{array}{l}\text { Pearson } \\
\text { Correlation }\end{array}$ & $.753^{* *}$ & $.689^{* *}$ & $.572^{* *}$ & $.625^{* *}$ & $.342^{* *}$ & 1 & $.614^{* *}$ \\
\hline & $\begin{array}{l}\text { Sig. } \\
\text { (2-tailed) }\end{array}$ & .000 & .000 & .000 & .000 & .000 & & .000 \\
\hline & $\mathrm{N}$ & 100 & 100 & 100 & 100 & 100 & 100 & 100 \\
\hline \multirow{3}{*}{$\begin{array}{l}\text { Environmental- } \\
\text { Economic } \\
\text { Aspect }\end{array}$} & $\begin{array}{l}\text { Pearson } \\
\text { Correlation }\end{array}$ & $.824^{* *}$ & $.730^{* *}$ & $.647^{* *}$ & $.713^{* *}$ & $.592^{* *}$ & $.614^{* *}$ & 1 \\
\hline & $\begin{array}{l}\text { Sig. } \\
\text { (2-tailed) }\end{array}$ & .000 & .000 & .000 & .000 & .000 & .000 & \\
\hline & $\mathrm{N}$ & 100 & 100 & 100 & 100 & 100 & 100 & 100 \\
\hline
\end{tabular}

**. Correlation is significant at the 0.01 level (2-tailed).

Table 5.1: Pearson Correlation

\begin{tabular}{|c|c|c|c|c|c|c|c|c|}
\hline & & $\begin{array}{c}\text { Sustainability at } \\
\text { Blue Collar } \\
\text { Workers' Level }\end{array}$ & $\begin{array}{c}\text { Economic } \\
\text { Aspect }\end{array}$ & $\begin{array}{l}\text { Social } \\
\text { Aspect }\end{array}$ & $\begin{array}{c}\text { Environmental } \\
\text { Aspect }\end{array}$ & $\begin{array}{c}\text { Socio- } \\
\text { Economical } \\
\text { Aspect }\end{array}$ & $\begin{array}{c}\text { Socio- } \\
\text { Environmental } \\
\text { Aspect }\end{array}$ & $\begin{array}{l}\text { Environmental- } \\
\text { Economic Aspect }\end{array}$ \\
\hline \multirow{2}{*}{$\begin{array}{l}\text { Sustainability } \\
\text { at Blue Collar } \\
\text { Workers' Level }\end{array}$} & $\begin{array}{l}\text { Pears on } \\
\text { Correlation }\end{array}$ & 1 & $.893^{* *}$ & $.828^{* *}$ & $.831^{* *}$ & $.593^{*}$ & $.753^{*}$ & $-824^{* *}$ \\
\hline & $\begin{array}{l}\text { Sig. } \\
(2 \text {-tailed) }\end{array}$ & & & & & & & .000 \\
\hline $0.00-0.20$ & & & & \multicolumn{5}{|c|}{ Almost no correlation } \\
\hline $0.21-0.40$ & & & & \multicolumn{5}{|c|}{ Low eorrelation } \\
\hline $0.41-0.60$ & & & & \multicolumn{5}{|c|}{ Moderate correlation } \\
\hline $0.61-0.80$ & $Z$ & $\angle$ & 1 & \multicolumn{5}{|c|}{ High correlation } \\
\hline $0.81-1.00$ & L $\quad$ L & L & $\angle$ & \multicolumn{5}{|c|}{ Perfect correlation } \\
\hline
\end{tabular}

The Pearson's Correlation table exhibits a correlation matrix. Here, we can see a perfect correlation between Sustainability at Blue Collar Workers' Level with Economic Aspect, Social Aspect, Environmental Aspect and Environmental-Economic
Aspect whereas; there is high correlation between dependent variable and Socio-Environmental Aspect and a moderate correlation between the dependent variable and Socio-Economic Aspect. 


\section{Identification of the Significance and Relevant Barriers of Sustainability Aspects at the Workers' Level in the Garments Industry of Bangladesh}

\subsection{Respondents' Feedback}

Table 6: Respondents' feedback

\begin{tabular}{|c|c|c|c|c|c|c|}
\hline \multirow{2}{*}{$\begin{array}{l}\text { Research } \\
\text { Question } \\
\text { Number }\end{array}$} & \multirow[b]{2}{*}{ Aspect } & \multicolumn{5}{|c|}{ Percentage of Respondents } \\
\hline & & $\begin{array}{c}\text { Strongly } \\
\text { Agree (5) }\end{array}$ & Agree (4) & Neutral (3) & $\begin{array}{c}\text { Disagree } \\
\text { (2) }\end{array}$ & $\begin{array}{c}\text { Strongly } \\
\text { Disagree } \\
\text { (1) }\end{array}$ \\
\hline 1 & Economic & 5 & 44 & 41 & 10 & 0 \\
\hline 2 & Social & 2 & 44 & 41 & 13 & 0 \\
\hline 3 & Environmental & 6 & 42 & 43 & 9 & 0 \\
\hline 4 & Economic-Social & 3 & 39 & 50 & 8 & 0 \\
\hline 5 & Socio-Environmental & 5 & 40 & 49 & 6 & 0 \\
\hline \multirow[t]{2}{*}{6} & Environmental-Economic & 9 & 37 & 41 & 13 & 0 \\
\hline & Target Research Question & 5 & 41 & 40 & 14 & 0 \\
\hline
\end{tabular}

\subsubsection{Economic Aspect}

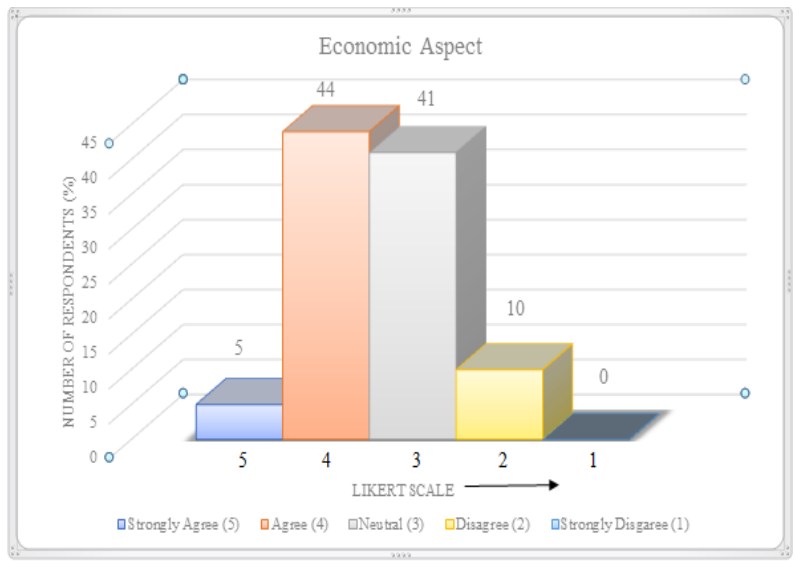

Figure 4: Economic Aspect

The above Figure 4 illustrates that only $5 \%$ and $44 \%$ of the respondents strongly agreed and agreed respectively with the statement that the economic aspect of their workplace was suitable and satisfactory for them. On the other hand, $41 \%$ of the respondents remain neutral in their opinion. However, $10 \%$ of the respondents disagreed with the statement. They indicated some of the problems which are acting as barriers of the economic aspect towards implementing sustainability at blue collar workers' level in Bangladeshi garments industries are such as low entry level wage, corruption at the time of increment, inactivity of quality control circle, lack of skill development programs. As the workers were scared of losing their jobs, so no respondent strongly disagreed with the research question of this aspect.

\subsubsection{Social Aspect}

The above Figure 5 illustrates that only $2 \%$ and $44 \%$ of the respondents strongly agreed and agreed respectively with the statement that the social aspect of their workplace was suitable and satisfactory for them. On the other hand, $41 \%$ of the respondents remain neutral in their opinion. However, $13 \%$ of the respondents disagreed with statement.

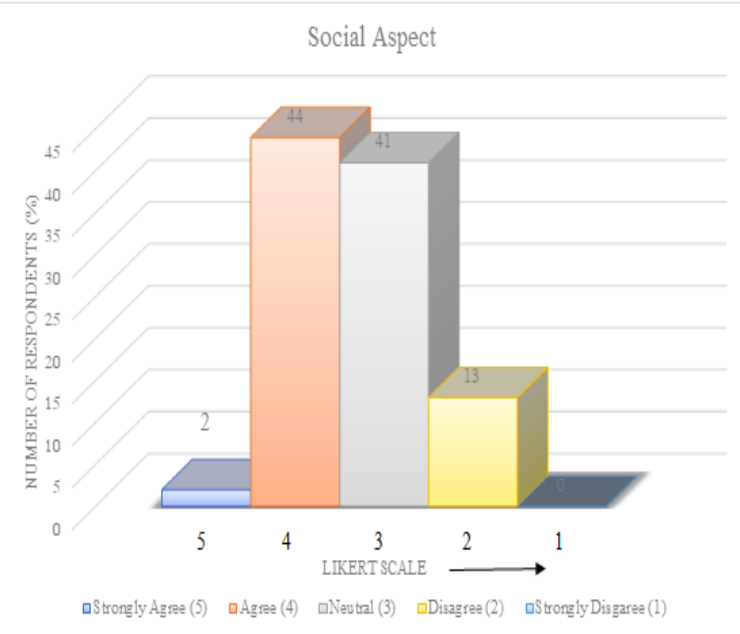

Figure 5: Social Aspect

They indicated some of the problems which are acting as barriers of the social aspect towards implementing sustainability at blue collar workers' level in Bangladeshi garments industries which are such as lower living standard, lack of health programs, insufficient educational support. The social state did not meet the expectation level of the workers. However, as it was within an acceptable range so that no respondent strongly disagreed with the research question of this aspect.

\subsubsection{Environmental Aspect}

The above Figure 6 illustrates that only $6 \%$ and $42 \%$ of the respondents strongly agreed and agreed respectively with the statement that the environmental aspect of their workplace was suitable and satisfactory for them. On the other hand, $43 \%$ of the 
respondents remain neutral in their opinion. However, $9 \%$ of the respondents disagreed with statement. We have found some of the problems which are acting as barriers of the environmental aspect towards implementing sustainability at blue collar workers' level in Bangladeshi garments industries are as follows: lack of knowledge about environment due to poor education level and lack of training and awareness programs.

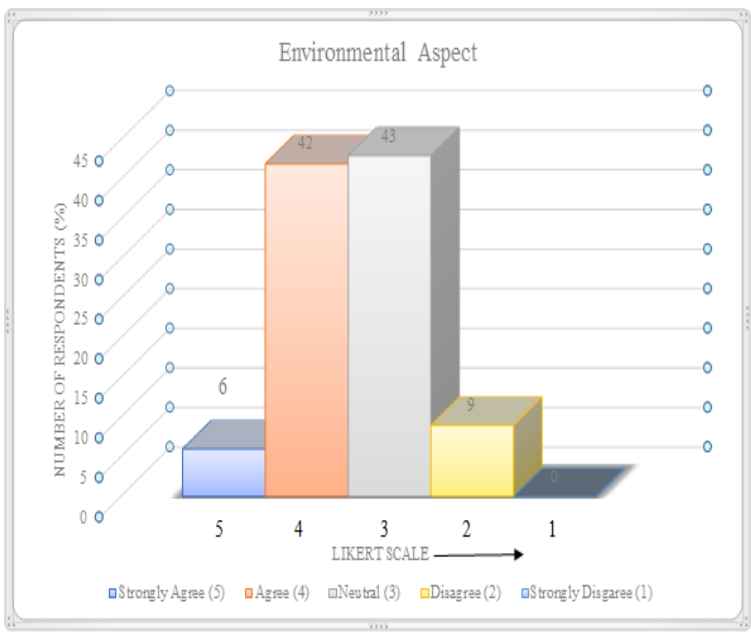

Figure 6: Environmental Aspect

\subsubsection{Economic-Social Aspect}

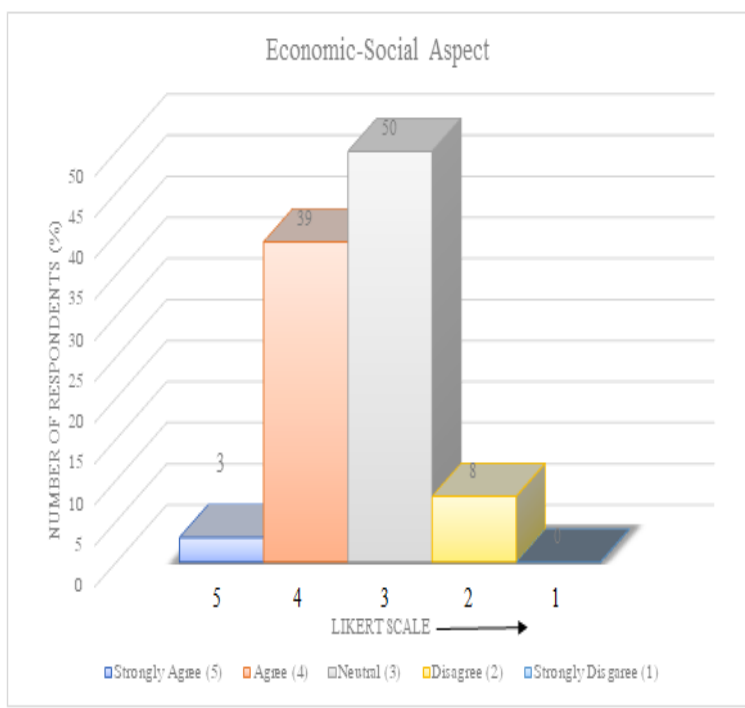

Figure 7: Economic-Social Aspect

The above Figure 7 illustrates that only 3\% and 39\% of the respondents strongly agreed and agreed respectively with the statement that the Economic-Social aspect of their workplace was suitable and satisfactory for them. On the other hand, 50\% of the respondents remain neutral in their opinion. However, $8 \%$ of the respondents disagreed and nobody strongly disagreed with the statement. The percentage of the research question might be affected by the lack of enlightenment of the workers about the issues related to this aspect.

\subsubsection{Socio-Environmental Aspect}

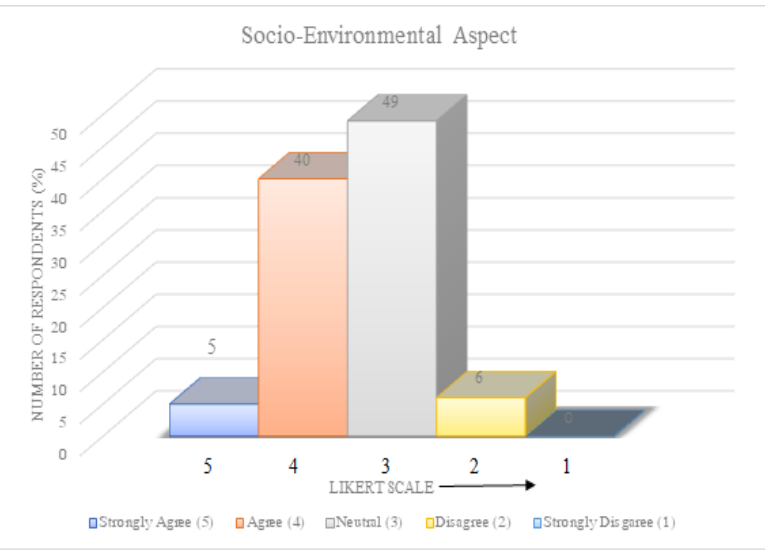

Figure 8: Socio-Environmental Aspect

The above Figure 8 illustrates that only $5 \%$ and $40 \%$ of the respondents strongly agreed and agreed respectively with the statement that the economic aspect of their workplace was suitable and satisfactory for them. On the other hand, $49 \%$ of the respondents remain neutral in their opinion. However, $6 \%$ of the respondents disagreed with statement. The percentage of the research question might also be affected by the lack of enlightenment of the workers about the issues related to this aspect.

\subsubsection{Environmental-Economic Aspect}

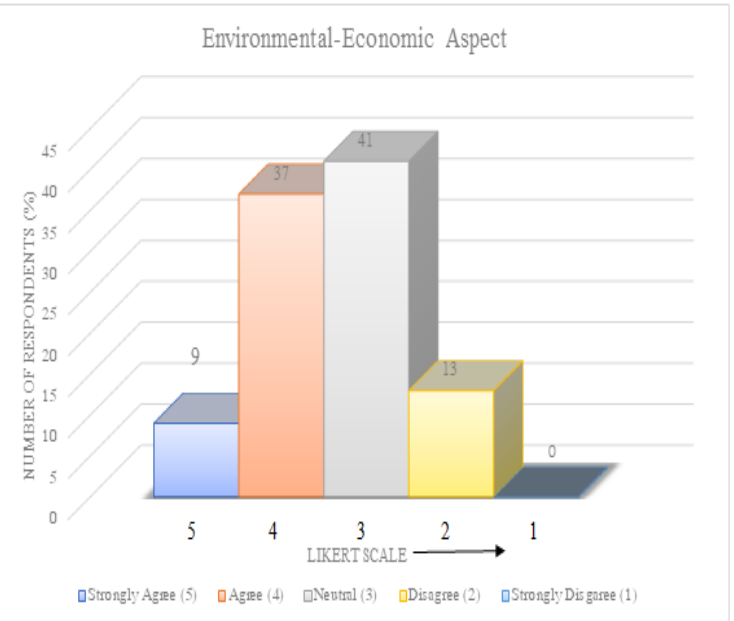

Fig 9: Environmental-Economic Aspect

The above Figure 9 illustrates that only $9 \%$ and $37 \%$ of the respondents strongly agreed and agreed respectively with the statement that the economic aspect of their workplace was suitable and satisfactory for them. On the other hand, $41 \%$ of the respondents remain neutral in their opinion. However, $13 \%$ of 


\section{Identification of the Significance and Relevant Barriers of Sustainability Aspects at the Workers' Level in the Garments Industry of Bangladesh}

the respondents disagreed with statement. The percentage of the research question might be affected by the lack of knowledge of the workers about the issues related to this aspect as like the previous two aspects.

\subsubsection{Target Research Question}

The Figure 10 illustrates that only 5\% and $41 \%$ of the respondents strongly agreed and agreed respectively with the statement that the economic aspect of their workplace was suitable and satisfactory for them. On the other hand, $40 \%$ of the respondents remain neutral in their opinion. However, $14 \%$ of the respondents disagreed and no one strongly disagreed with research question. The respondents who strongly agreed and agreed might be getting more facilities than the other respondents or the existing facilities might be meeting their expectation level. Some issues might be affecting the respondents who were neutral in their statement. Lack of knowledge was also a probable reason behind this kind of response. Minor issues were also thought as the barriers for the respondents who disagreed with the target research question.

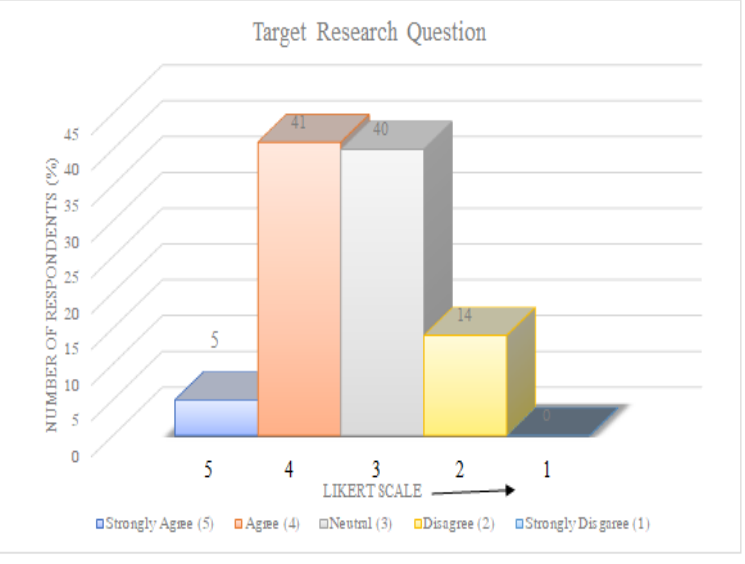

Figure 10: Target Research Question

\section{KEY FINDINGS}

Economic aspect is the most significant predictor whereas Environmental-economic aspect was the least significant one. Poor salary and biased increment system is a major concern for the blue collar workers. Inadequate support from the factory to improve the accommodation and transport system is also a major barrier towards achieving sustainability at the blue collar workers' level. Lack of knowledge of the workers about the environment related issues is also a major barrier towards obtaining sustainability.

\section{CONCLUSION}

Sustainable development issues related to global environment concerns has not been well addressed in action. Although some planning initiatives have taken at national, regional and local levels but when it comes in implementation, not much progress has been made. There seem to be lack of commitment and awareness among local agencies and communities regarding to implementation of sustainable development initiatives. This study was an initiative to find out the sequence of significance and barriers of each sustainable aspect. It is clear from the study that economic aspect was the most significant predictor whereas environmental-economic was the least significant one. The study also reflects the barriers which are acting as the obstacle towards obtaining sustainability at workers' level in Bangladeshi garments. It is never easy to transform the lifestyle of a person. It has to begin with awareness and continuous campaign. It is hoped that this study will help the garments industry owners to eliminate the barriers associated with each aspect to achieve sustainability.

\section{REFERENCES}

[1] Williams CC, Millington AC. The diverse and contested meanings of sustainable development. Geographical Journal. 2004 Jun; 170(2):99-104.

[2] Bakari ME. The dilemma of sustainability in the age of globalization: a quest for a paradigm of development. Lexington Books; 2017 Sep 5.

[3] Sholanke AB, Opeyem IL. Implementation of Green Design Strategies by Architects in Southwest Nigeria. International Journal of Innovative Technology and Exploring Engineering. 2019; 8(9):431-8.

[4] Black IR, Cherrier H. Anti-consumption as part of living a sustainable lifestyle: daily practices, contextual motivations and subjective values. Journal of Consumer Behaviour. 2010 Nov; 9(6):437-53.

[5] Shaker RR. The spatial distribution of development in Europe and its underlying sustainability correlations. Applied Geography. 2015 Sep 1; 63:304-14.

[6] Wilding R, Wagner B, Gimenez C, Tachizawa EM. Extending sustainability to suppliers: a systematic literature review. Supply Chain Management: an international journal. 2012 Aug 3.

[7] Jamrozy U. Marketing of tourism: a paradigm shift toward sustainability. International Journal of Culture, Tourism and Hospitality Research. 2007 Jun 12.

[8] Penz E, Hofmann E, Hartl B. Fostering sustainable travel behavior: Role of sustainability labels and goal-directed behavior regarding touristic services. Sustainability. 2017 Jun; 9(6):1056

[9] Perera A, Pino SPdel. The 4 biggest barriers to corporate sustainability [Internet]. Greenbiz. [cited 2019,Jul20]. Available from: https://www.greenbiz.com/blog/2013/03/07/4-biggestbarriers-corporate-sustainability

[10] SPSS - What Is It? [Internet]. SPSS tutorials SPSS What Is It Comments. [cited 2019,Jul30]. Available from: https://www.spss-tutorials.com/spss-what-is-it/

[11] Unknown. Blog Post 6 - The Three Spheres of Sustainability [Internet]. Blog Post 6 - The Three Spheres of Sustainability. 1970 [cited 2019Aug5]. Available from: http://shawnpricedpp.blogspot.com/2014/02/blog-post-6three-spheres-of.html.

[12] Dissertation and Research Consulting For Statistical Analysis [Internet]. Statistics Solutions. [cited 2019,Aug20]. Available from: https://www.statisticssolutions.com/

[13] Hashemkhani Zolfani S, Sedaghat M, Maknoon R, Zavadskas EK. Sustainable tourism: a comprehensive literature review on frameworks and applications. Economic Research-Ekonomska Istraživanja. 2015 Jan 1; $8(1): 1-30$.

[14] VIF [Internet]. Lean Manufacturing and Six Sigma Definitions. [cited 2019,Aug20]. Available from: http://www.leansixsigmadefinition.com/glossary/vif/ 